\title{
Stage IA1 Cervical Cancer AJCC v6 and v7
}

National Cancer Institute

\section{Source}

National Cancer Institute. Stage IA1 Cervical Cancer A/CC v6 and v7. NCI Thesaurus.

Code C6314.

Stage IA1 includes: T1a1, N0, M0. T1a1: Measured stromal invasion $3.0 \mathrm{~mm}$ or less in depth and $7.0 \mathrm{~mm}$ or less in horizontal spread. N0: No regional lymph node metastasis. M0: No distant metastasis. (AJCC 6th and 7th eds.) 